\title{
血管内皮のNO産生系と $\mathrm{Ca}^{2+}$ 機構
}

\author{
守時 英喜*, 久山 哲廣*, 近藤 渉*, 高石 喜久**
}

徳島大学薬学部薬物学教室*, 生薬学教室**

\section{緒 言}

血管内皮細胞における NO synthase (NOS) の活性化には細胞外から流入する $\mathrm{Ca}^{2+}$ (Ca) に大部分は依存しているが，一部はストアからの Ca も寄与している。しかし流入から NOS の 活性化に至る機構については解明されていない。私達はCa-ATPase阻害剤シクロピアゾン酸 (CPA) やサプシガージン（TG）が NO を介して血管を弛緩させることを報告したが 1，2）、 tyrosine kinase 阻害剤（ハービマイシン A、ゲニステイン） や Ca チャネルブロッカー （SKF96365，ニフェジピン）を用いて内皮の NO 産生に必要な Caの供給過程とその機構を検 討した結果, NOS の活性化に必要な Caのほとんどはいわゆる受容体作動性チャネルを介して細 胞外から流入したCaによっていること（投稿中）、その流入のシグナル伝達路に tyro sine kin ase (TK) が関与しているらしいこと ${ }^{3}$ )、内皮でも新しいタイプの NOS が誘導されることを明かに しており, 内皮の $\mathrm{Ca}$ 機構という視点からまとめた。

NO の産生の引金になる Ca 流入系の解明と, これに影響を与える薬物は今後の創薬のターゲ ットの一つになると考えられる。私達はすでにエンドトキシン（LPS）とインターロイキンー $1 \beta(I L-1 \beta)$ による血管平滑筋 NOS の発現/誘導に TK が介在しているらしいことを報告した 4 )。 抗リュウマチ作用を有するニシキギ科クロズル(Triptergium Wilfordii var regelii) 由来の化合物 卜 リプトキノンA 5 ) (TQA) はNOS 誘導を阻害するが, この機構としてサイトカインの産生/遊 離の抑制, あるいはサイトカインによって刺激される NOS の発現/誘導 に係わるシグナル伝達路の蛋白リン酸化阻害の可能性を示唆した。また キノン骨格がその阻害活性に必要であることを報告した（第27回薬物活 性シンポジウム）。今回は血管内皮のCa機構とも関連させて検討した。

\section{実験結果と考察}

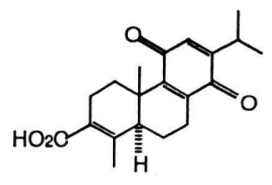

TQA

TQA は LPS / IL-1 $\beta$ によるNOS の誘導を阻止する

内皮を除去したラット胸部大動脈標本にLPS $100 \mathrm{ng} / \mathrm{ml}$ 、あるいは IL-1 $1 \beta 0.3 \mathrm{ng} / \mathrm{ml}$ を 6 時間 処置しておくとNOS が誘導され、アルギニンを適用すると血管は弛緩を発現するようになり、 NO 産生のマーカーとしての cGMP の産生と、血管平滑筋の培養細胞 NO2“の蓄積量が増大して いた。これらの反応のいずれもが NO pathway 阻害剂と蛋白合成阻害剤によって抑制されたが, カルモジュリン阻害剤の影響を受けていないことから、LPS/IL-1 1 によって iNOS が誘導され結 果アルギニンから NO が産生されために引き起こされた反応であると推定した $\left.{ }^{6,7}\right)$ 。さらに TK 阻害剤ハービマイシンA (HM - A) やアーブスタチンなどはこの NOS の誘導を完全に阻止 したので、血管平滑筋 NOS の誘導/発現経路にはTK が介在していると推測した。 
TQA を血管摘出直後から適用しておくとアルギニンの効果は発現しなくなり、この LPS や IL-1 $\beta$ のプライミング 効果は完全に阻止された (図 1)。LPS による mRNA お発現はTQA $30 \mu \mathrm{M}$ で $62.3 \pm 2.3 \%$ が、デキサメサゾン $1 \mu \mathrm{M}$ で78.3 $\pm 6.2 \%$ が抑制された。

TQA の阻害効果はTK 阻害剤の効果之類似していることから TQA がTK 阻害作用をもってい る可能性が示唆された。
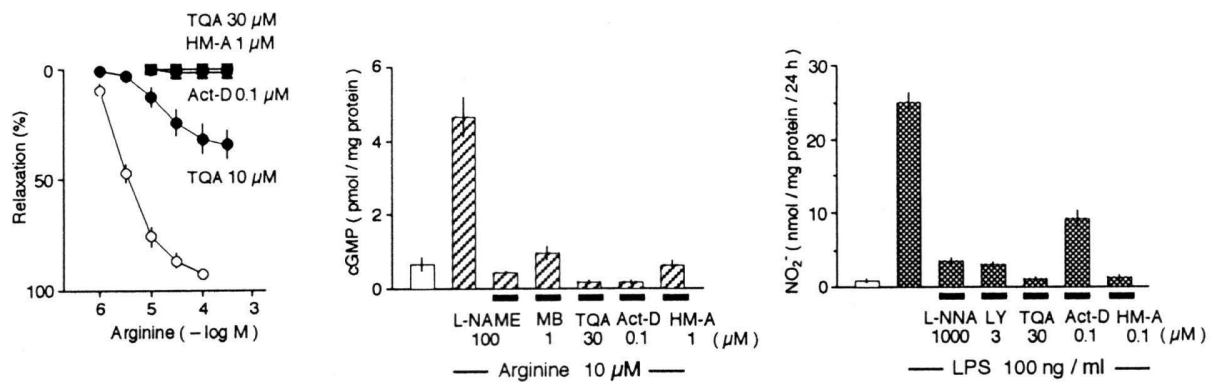

Fig.1. Inhibition by actinomycin $D$, herbimycin $A$, NO pathway inhibitors and TQA on the LPS-primed, L-arginine-induced relaxation and CGMP formation in rat thoracic aorta, and effect of TQA on the mRNA expression. Endotoxin was applied for $8 \mathrm{~h}$, then the effect of Larginine was examined. The inhibitors were applied $60 \mathrm{~min}$ before treatment with LPS, and were present throughout the experiments. Amounts of CGMP were measured after incubation with $10 \mathrm{mM}$ L-arginine for $60 \mathrm{sec}$. The cultured cells were treated with $300 \mathrm{ng} / \mathrm{ml}$ of LPS for $24 \mathrm{~h}$ in the absence and presence of inhibitors. The medium contained $400 \mathrm{~mm}$ arginine. Amounts of nitrite accumulated in $24 \mathrm{~h}$ were determined by Griess method.

\section{CaATPase 阻害剂の作用}

小胞体のCa-ATP ase を阻害する CPA，TG はそれぞれ $0.1 \mu \mathrm{M}$ および $1 \mathrm{nM}$ からラット胸部大 動脈を弛緩させ、またNO 産生のマーカーとしての cGMPの産生の増加が認められた（図 2 ）。 この弛緩作用と cGMPの増加は内皮の除去, NOS 阻害剂ニトロアルギニン (3 $\mu \mathrm{M} \sim)$, ラヂカル スカベンジャーであるへモグロビン (0.1 $\mu \mathrm{M}$ ） あるいはグアニレートサイクレース 阻害剤 LY83583 (0.1 $\mu \mathrm{M} \sim)$ などによって抑制された。
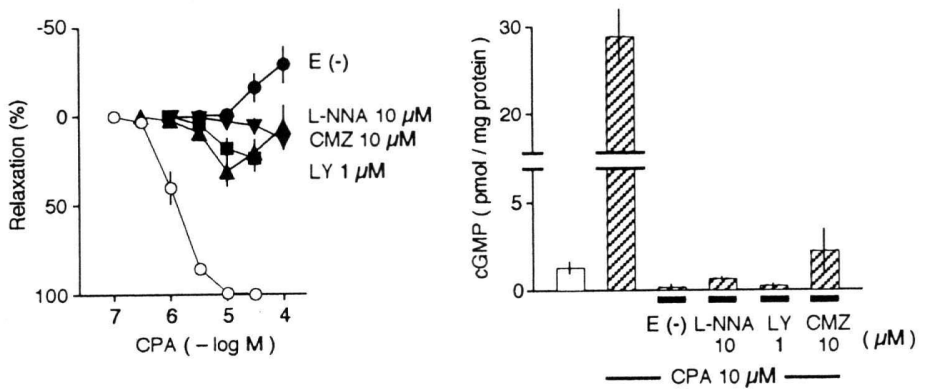

Fig.2. Effects of removal of the endothelium, NO pathway inhibitors and calmodulin inhibitors on the relaxation and CGMP production induced by cyclopiazonic acid. Experimental conditions were as for figure 1.

血管内皮 NOS の活性化に必要なCa の由来

カルモジュリン阻害剤カルミダゾリウム $(10 \mu \mathrm{M}), \mathrm{W}-7$ (100 $\mu \mathrm{M})$ は Ca-ATPase 阻害剤による 弛緩と·cGMP 産生をほぼ完全に抑制した。一方, 受容体を介してNO 産生を引き起こす ACh の弛緩作用と cGMP の産生も抑制した（図 2)。 
Krebs 液中のCa 除去するとCaATPase による弛緩もcGMPの増加も消失したが, ACh には 一部 Ca - free 抵抗性の部分が認められた（図 3 )。しかしカルミダゾリウム存在下でも $\mathrm{Ca}$ free下でもニトロプルシドの作用は影響を受けなかった。
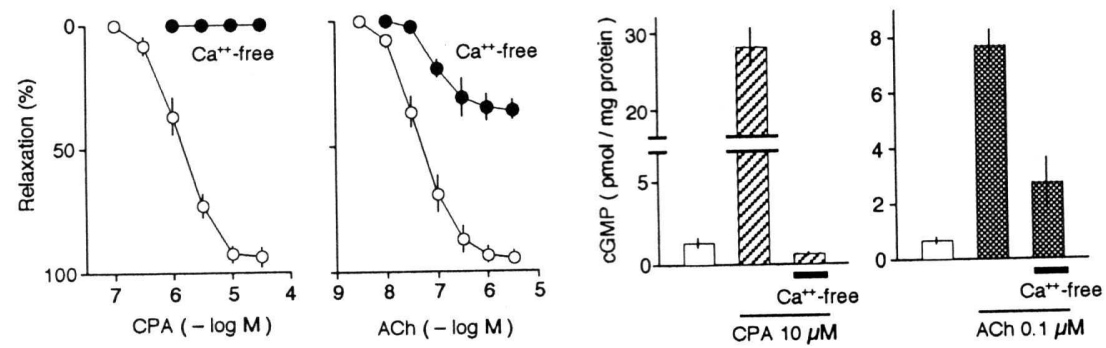

Fig.3. Effect of removal of $\mathrm{Ca}^{2+}$ on the relaxation and CGMP production induced by cyclopiazonic acid or $\mathrm{ACh}$. Experimental conditions were as for figure 1.

すなわち図 4 に示すように, CaATPase阻害剤は内皮 細胞内 $\mathrm{Ca}$ の増加を引き起こすことにより $\mathrm{Ca}$ - カルモシ ュリン依存性の cNOS を活性化させた結果 NO を産生 すると考えられる。この増加したCa は細胞外からの Ca に由来していると推測される。すなわち, CaATPase阻 害剤 CPA や TG は内皮細胞の $\mathrm{Ca}$ ストアに局在する $\mathrm{Ca}$ ATPase は Caをストアに取り込むポンプとして機能し ている。内皮細胞内において Ca は Ca ポンプによって ストア 内に取り込まれると同時に絶えず細胞内へ漏出 しているため, CaATPase 阻害剤 CPA や TG がポンプ を阻害すると急速に枯渴する。貯蔵 Ca が枯渴したとい う情報が細胞膜 Ca チャネルに伝達され, チャネルが開 口する結果 cNOS の活性化に必要な量のCa が流入する。

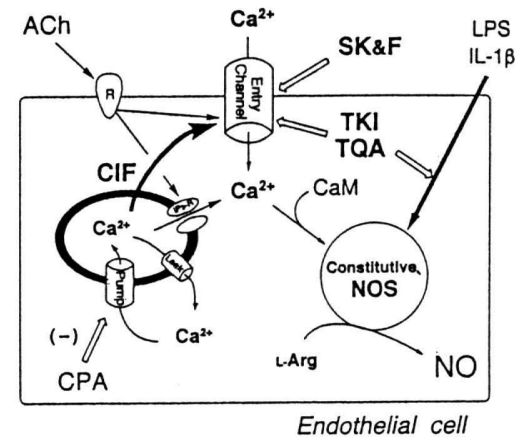

Fig.4. Possible involvement of tyrossine kinase in Ca entry process, and sites of actioon of TQA. TKI, tyrosine kinase inhibitors; CIF, calcium influx factor.

血管内皮の $\mathrm{Ca}$ 流入チャネル

CaATP ase 阻害剤 CPA とACh とによる弛緩は電位依存性 Caチャネルブロッカーであるニフ エジピンでは全く影響を受けなかった。これに対して受容体作動性 Ca チャネルブロッカー/非 選択性カチオンチャネルブロッカーといわれているSKF96365 $50 \mu \mathrm{M}$ 20 分間適用しておく
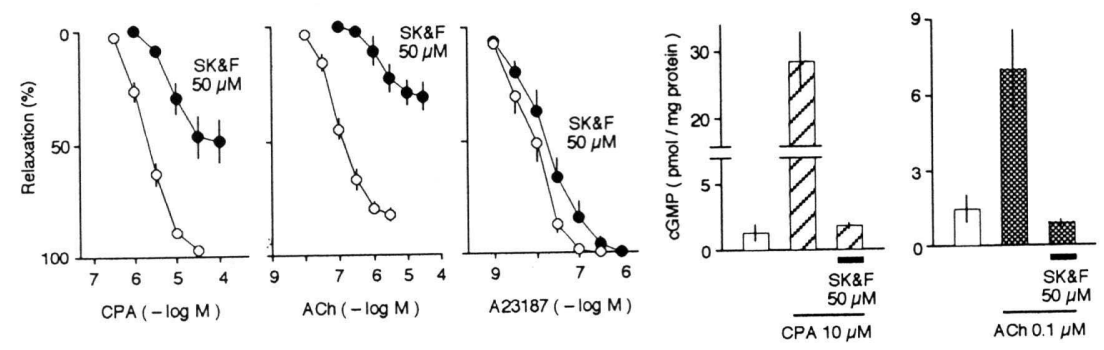

Fig.5. Inhibition by SK\&F96365 of the relaxation and CGMP formation induced by cyclopiazonic acid or $A C h$ in rat thoracic aorta. A23187 was used for comparison. SK\&F96365 was applied $30 \mathrm{~min}$ before addition of relaxants. 
とACh および CPA による血管の内皮依存性弛緩も CGMP 産生も抑制された（図 5 ）。しかし 対照に用いたCaイオノホアーA23187 に対してSKF-96365 は無効であった。また、受容体 作動性 Ca チャネルを阻害するといわれている Ni も CPA とAChの作用を抑制した。

以上のことからも、CaATPase阻害剤によるNOS 活性化に必要な Ca は小胞体由来ではなく、 細胞外に由来しており、受容体作動性 Ca チャネルを経由して流入するという考えを裏付ける。

一方、ACh の弛緩作用には $\mathrm{Ca}$ - free 抵抗性の部分が存在するので、一部はストアから遊離す るCaにも依存していると考えられる。

CPA とACh の弛緩作用之, NO 産生に対する TQA の抑制効果

CPA と、血管内皮の受容体を介して作用を発現する ACh の血管弛緩作用は TK 阻害剂 HM-A (1 3 $\mu \mathrm{M})$ あるいは TQA (10 100 $\mu \mathrm{M})$ 共存下では抑制されたが、Ca イオノホアーA23187 の内皮依存性弛緩作用は影響を受けなかった。すなわち TQA は血管内皮細胞において受容体刺 激でひきおこされる Ca の流入過程、多分 Ca チャネルの開口過程に作用していること、また TK が Ca 流入過程に関与していることを示唆している。TQA と TK 阻害剤の効果の類似性はここ でも観察された(図 6)。
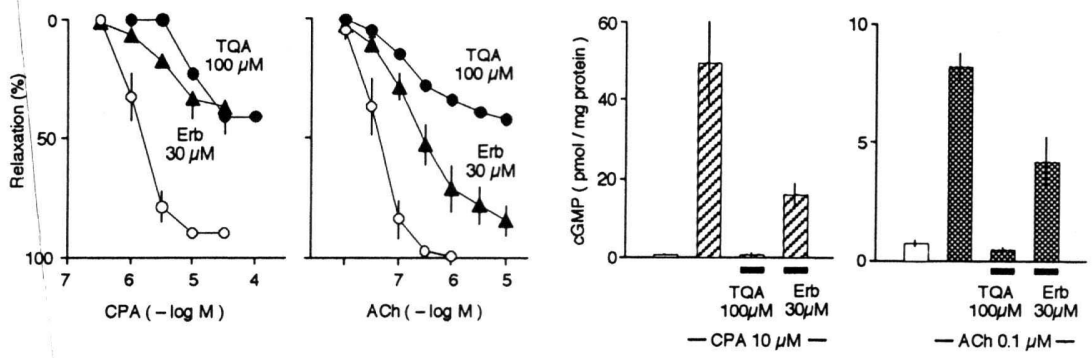

Fig. 6 Effects of erbstatin analog and TQA on the relaxation and CGMP formation induced by cyclopiazonic acid or ACh.

内皮の cNOS 誘導とTQA

エンドセリンー 3 はラット胸部大動脈を殆ど弛緩させないがLPS $(100 \mathrm{ng} / \mathrm{ml})$ を適用してお くとET-B受容体を介する顕著な内皮依存性弛緩反応がみられるようになる。NO pathway 阻害剤 で抑制されることからNO が介在している反応である. あらかじめ蛋白合成阻害薬シクロへキシ ミド $(10 \mu M)$ や TK 阻害剤 HM- A $(1 \mu M)$ を共存させておくとこの現象は認められなくなった。 従ってET-3-弛緩は内皮で LPSによって誘導されるNOS が司っていると考えられる.
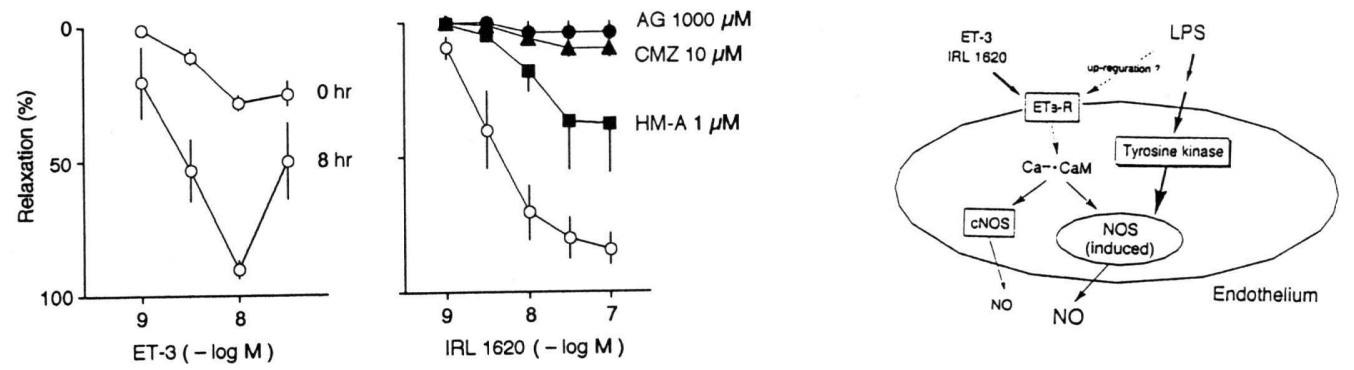

Fig.7. Effects of tyrosine kinase inhibitors and aminoguanidine on the LPS-promoted initiation of endothelin-3-induced relaxation of rat aorta. IRL1620 was used as a selective ET-B receptor agonist. 
ところが ET-3 の作用は細胞外の Ca とカルモジュリンに依存している点では cNOS の性質を具 えているにも関わらず、iNOS の阻害剂アミノグアニジン (0.3 1 mM) によって選択的に抑制さ れるようにiNOS の性質も示すという奇妙な一面をもっている（図 7 ）。

TQA あるいは tyrosine kinase 阻害剂や蛋白合成阻害剂を共存させておくと TK 阻害剤と同じ ようにLPS によって内皮で誘導されるよ考えられるNOS の発現を抑えた。

\section{まとめ}

CaATPase 阻害剂は血管内皮細胞において CaストアのCaポンプを阻害してストアを枯渴さ せるが、その情報が細胞膜の Ca チャネルに伝達され、その結果チャネル開口して Ca が流入し てNOS が活性化されると推測している $\left.{ }^{1,2}\right)$ 。平滑筋では Ca Influx Factor (CIF) 8 ) の関与が提唱 されている。私達の研究で Ca 枯渴からCa 流入に至るプロセスはTK 阻害剤で阻止されるので、 この情報に垟はTK が司っているのではないかと推測している。CPA の作用はすべて細胞外 Ca に依存しており、内皮への Ca 流入は SKF96365 感受性のいわゆる受容体依存性 Ca千ャネルと 考えられ、このチャネルの活性化にTK が関係しているようである。一方, 内皮依存性驰緩物 質の代表である ACh 弛緩はCa free 抵抗性の部分が認められることから、ストアから放出され たCaもNOSの活性化に関与していることを示唆している。

血管内皮においても NOS が誘導されることを機能面で明かにしたが, 誘導型であるにも関わ らずCa-カルモジュリン依存性である。内皮の NOS 誘導に必要な Ca の起源はまだ不明である がCaストアとの関連については今後の興味ある課題である。

キノイド型ジテルペン棈造を有するトリプトキノン誘導体は TK 阻害活性をもつと推定され、 シグナル伝達経路に TK が関与していると考えられる血管内皮の Ca チャネルをはじめ様々なイ オンチャネルの機能にも影響を与えることが予測される興味深い化合物である。

(1) Moritoki et al., Br.J.Pharmacol., 111655 (1994); (2) Moritoki et al., Life Sci., 54153 (1994); (3) Hisayama et al., Lapn.J.Pharmacol., 67181 (1995); (4) Moritoki et al., in press, (1994); (5) Takaishi et al., Tetrahedron Letts., 337177 (1992); (6) Moritoki et al., Br.J.Pharmacol., 107361 (1992); (7) Moritoki et al., Arch.Int.Pharmacodyn., 372152 (1994); (8) Randriamampita \& Tssien, Nature 364809 (1993)

\section{Endothelial No production and $\mathrm{Ca}^{2+}$}

Hideki Moritoki, Tetsuhiro Hisayama, Wataru Kondoh, Yosihisa Takaishi. Faulty of Pharmaceutical Sciences, Univ.of Tokushima, Tokushima 770, Japan.

Folia Pharmacol. Jpn. 106 (suppl.1), $97 \mathrm{P} \sim 101 \mathrm{P}$ (1995)

We examined the characteristics of $\mathrm{Ca}^{2+}$ (Ca) signaling pathway for activation of endothelial NOS, with reference to 1) Ca entry triggered by depletion of stored $\mathrm{Ca}$ in the endothelium, 2) Ca entry channels in response to depletion of the stores, and 3) possible involvement of tyrosine kinase in the signaling pathway. In vascular endothelium, Ca-ATPase inhibitors depletes $\mathrm{Ca}$ stores by inhibiting $\mathrm{Ca}$ pump of the stores, which in turn triggers influx of $\mathrm{Ca}$ and activates cNOS and NO production. The channels through which $\mathrm{Ca}$ enter into the endothelial cells following agonist-stimulation or Ca-ATPase inhibitors seem to be of the SK\&F96365-sensitive Ca channels. However, in the case of ACh, intracellularly stored $\mathrm{Ca}$ in part participates in NOS activation. Tyrosine kinase may be involved in the signaling pathway for $\mathrm{Ca}$ entry or Ca channel mechanism, because tyrosine kinase inhibitors inhibited effects of Ca-ATPase inhibitors. Triptoquinone $A$ which has been reported to inhibit NOS induction primed by LPS/IL-1 $\beta$ attenuated endothelium-dependent relaxation induced by Ca-ATPase inhibitors and agonists, possibly via tyrosine kinase inhibition. 